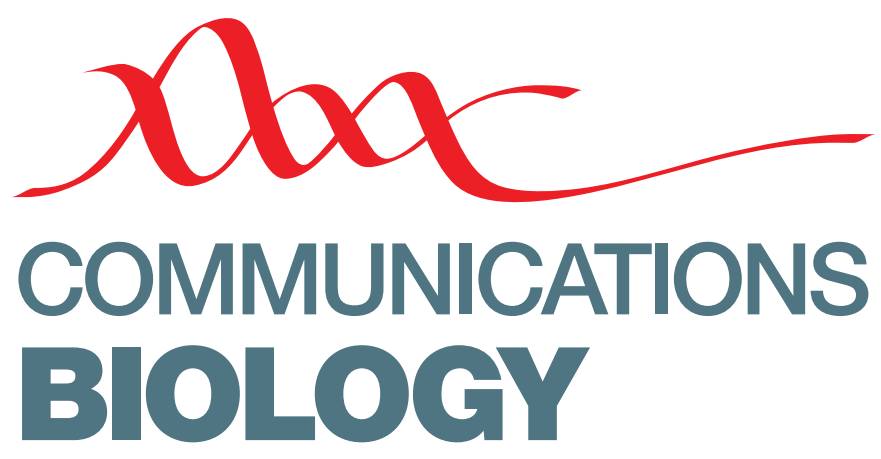

Check for updates

https://doi.org/10.1038/s42003-020-01196-6 OPEN

\title{
Author Correction: Force-exerting perpendicular lateral protrusions in fibroblastic cell contraction
}

\author{
Abinash Padhi, Karanpreet Singh, Janusz Franco-Barraza (D, Daniel J. Marston, Edna Cukierman (1), \\ Klaus M. Hahn (1), Rakesh K. Kapania \& Amrinder S. Nain (1)
}

Correction to: Communications Biology https://doi.org/10.1038/s42003-020-01117-7, published online 21 July 2020.

In the original version of the published Article, there were errors in the placement of the black dashed lines in Fig. 3c. The errors affected the interpretation of the undeflected position of neighboring fibers. The figure has been replaced in the PDF and HTML versions of the Article.

Published online: 21 August 2020

(c) Open Access This article is licensed under a Creative Commons Attribution 4.0 International License, which permits use, sharing, adaptation, distribution and reproduction in any medium or format, as long as you give appropriate credit to the original author(s) and the source, provide a link to the Creative Commons license, and indicate if changes were made. The images or other third party material in this article are included in the article's Creative Commons license, unless indicated otherwise in a credit line to the material. If material is not included in the article's Creative Commons license and your intended use is not permitted by statutory regulation or exceeds the permitted use, you will need to obtain permission directly from the copyright holder. To view a copy of this license, visit http://creativecommons.org/licenses/by/4.0/.

(C) The Author(s) 2020 